\title{
Nursing workload in burn intensive care unit
}

\author{
Carga de trabalho de enfermagem em unidade de terapia intensiva destinada a pacientes com queimaduras \\ Carga de trabajo de enfermaría en Unidad de Terapia Intensiva destinada a pacientes con quemaduras
}

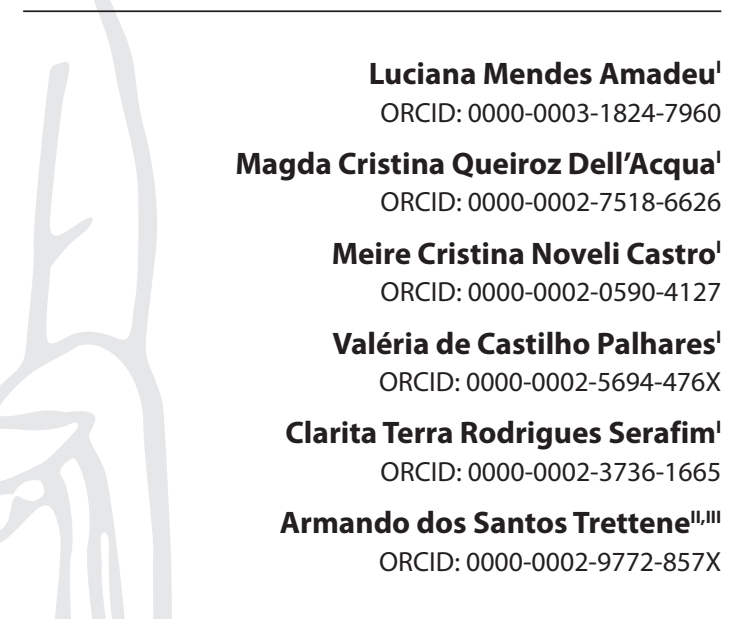

'Universidade Estadual Paulista "Júlio de Mesquita Filho". Botucatu, São Paulo, Brazil.

"Universidade de São Paulo, Hospital de Reabilitação de Anomalias Craniofaciais. Bauru, São Paulo, Brazil. 'I' Universidade Paulista. Bauru, São Paulo, Brazil.

How to cite this article: Amadeu LM, Dell'Acqua MCQ, Castro MCN, Palhares VC, Serafim CTR, Trettene AS. Nursing workload in burn intensive care unit. Rev Bras Enferm. 2020;73(Suppl 1):e20190446. doi: http://dx.doi.org/10.1590/0034-7167-2019-0446

Corresponding author: Armando dos Santos Trettene E-mail: armandotrettene@usp.br

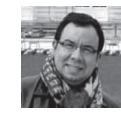

EDITOR IN CHIEF: Antonio José de Almeida Filho ASSOCIATE EDITOR: Hugo Fernandes

Submission: 06-10-2019 Approval: 01-21-2020

\begin{abstract}
Objectives: To measure the nursing workload in the Burn Intensive Care Units and evaluate its association with clinical variables, length of stay, and outcome of hospitalization. Methods: Cross-sectional study carried out in a Brazilian public large hospital. The study included 33 patients. The nursing workload was assessed using the Nursing Activities Score (NAS) every 24 hours. We performed 447 Nursing Activities Score assessments. For the statistical analysis, Student's $t$-test, ANOVA, and Spearman's correlation test were used. The considered significant difference was $5 \%(p \leq 0.05)$. Results: The Nursing Activities Score mean was $84 \%$ ( \pm 4.4 ), which corresponded to 20.2 hours. There was an association between the nursing workload and the patient's severity $(p<0.010)$, burned body surface $(p=0.010)$, and hospitalization outcome $(p=0.020)$. Conclusion: Burn victims, assisted in the ICU, demanded a high nursing workload, which was influenced by clinical aspects and the hospitalization outcome. These findings point to the need to reconsider the nurse staffing related to this care profile.
\end{abstract}

Descriptors: Workload; Nursing; Intensive Care Unit; Burns; Burn Units.

\section{RESUMO}

Objetivos: Mensurar a carga de trabalho de enfermagem em Unidade de Terapia Intensiva destinada ao tratamento de pacientes com queimaduras e avaliar sua associação com variáveis clínicas, tempo e desfecho da internação. Métodos: Estudo transversal realizado em um hospital público e de grande porte brasileiro, que incluiu 33 pacientes. A carga de trabalho de enfermagem foi avaliada por meio do Nursing Activities Score (NAS) a cada 24 horas. Foram realizadas 447 avaliações Nursing Activities Score. Para a análise estatística, utilizaram-se os testes $t$ de Student, ANOVA e Correlação de Spearman. Considerou-se a diferença significante de 5\% ( $p \leq 0,05)$. Resultados: A média Nursing Activities Score foi de $84 \%( \pm 4,4)$, que correspondeu a 20,2 horas. Houve associação entre a carga de trabalho de enfermagem e a gravidade do paciente $(p<0,010)$, superfície corporal queimada $(p=0,010)$ e desfecho da internação $(p=$ 0,020 ). Conclusão: Pacientes vítimas de queimaduras, atendidos em UTI, demandaram elevada carga de trabalho de enfermagem, que foi influenciada por aspectos clínicos e desfecho da internação. Esses achados apontam a necessidade de se reconsiderar o dimensionamento de pessoal relacionado a esse perfil assistencial.

Descritores: Carga de Trabalho; Enfermagem; Unidade de Terapia Intensiva; Queimaduras; Unidades de Queimados.

\section{RESUMEN}

Objetivos: Mensurar la carga de trabajo de enfermaría en Unidad de Terapia Intensiva destinada al tratamiento de pacientes con quemaduras y evaluar su asociación con variables clínicas, tiempo y desenlace de la internación. Métodos: Estudio transversal realizado en un hospital público y de grande porte brasileño, que ha incluido 33 pacientes. La carga de trabajo de enfermaría ha sido evaluada por medio del Nursing Activities Score (NAS) a cada 24 horas. Han sido realizadas 447 evaluaciones Nursing Activities Score. Para el análisis estadístico, se han utilizado los testes $t$ de Student, ANOVA y Correlación de Spearman. Se ha considerado la diferencia significante de $5 \%(p \leq 0,05)$. Resultados: La media Nursing Activities Score ha sido de $84 \%( \pm 4,4)$, que ha correspondido a 20,2 horas. Hubo asociación entre la carga de trabajo de enfermaría y la gravedad del paciente $(p<0,010)$, superficie corporal quemada $(p=0,010)$ y desenlace de la internación $(p=0,020)$. Conclusión: Pacientes víctimas de quemaduras, atendidos en UTI, demandaron elevada carga de trabajo de enfermaría, que ha sido influenciada por aspectos clínicos y desenlace da internación. Esos encontrados apuntan la necesidad de reconsiderarse el dimensionamiento de personal relacionado a este perfil asistencial.

Descriptores: Carga de Trabajo; Enfermaría; Unidad de Terapia Intensiva; Quemaduras; Unidades de Quemados. 


\section{INTRODUCTION}

The development of the process of nursing work is tied to many variables that include quantitative and qualitative aspects. Among them, studies highlight the adequacy of human resources, which incurs directly on the quality of assistance, patient's security, and costs reduction ${ }^{(1-2)}$.

Hospital units assist different patients' profiles. However, it is evident that the care for the seriously ill patient denotes significant complexity. This context includes care units for patients who have suffered burns, particularly the Intensive Care Unit (ICU). These patients, in addition to physical, psychological, and social consequences, often present systemic compromise associated with complications, various surgical procedures, and infections ${ }^{(3-4)}$.

In these units, care and management complexity is evidenced through the use of advanced technology, frequent decision-making, coping with conflicts, need for effective communication, interdisciplinary work, the experience of death and grief, approach to patients and family members who are in unfavorable physical and psychological conditions. Thus, an appropriate allocation of nursing staff is essential, in addition to experienced and specialized professionals ${ }^{(4-5)}$.

It is known that an undersized team, in addition to the devastating influence on the quality of care, affect workers' health, resulting in discontent, physical and psychological overload, absenteeism and stress, including burnout ${ }^{(6)}$. In contrast, oversized nursing teams bring high costs to health institutions and systems ${ }^{(7)}$. Nursing stands out among the most stressful professions, and nurse professionals often experience physical and psychological distress ${ }^{(8-9)}$.

In this context, the measurement of nursing workload has been referred to as an essential managerial and care indicator, as it allows, among others, the adequate staff sizing ${ }^{(10)}$.

In order to measure the nursing workload reliably and to consider the care complexity and the work process, several instruments have been developed. Among them, the Nursing Activities Score (NAS) stands out. It allows measuring direct and indirect nursing activities, in addition to being applicable in different contexts ${ }^{(11)}$, which is why we have chosen it for the present study. The NAS was translated and validated for the Brazilian reality ${ }^{(12)}$.

Researchers from different segments of nursing, especially those related to management, have dedicated themselves to the development of studies that address the nursing workload. However, there are gaps in knowledge on this topic related to patients affected by burns, attended in the ICU.

Thus, we expected that this study could contribute to health managers' prediction of human resources, in addition to contributing to the quality of the process of care of burn victims in the ICU.

\section{OBJECTIVES}

To measure the nursing workload in a Burn Intensive Care Unit and evaluate its association with clinical variables, length of stay, and hospitalization outcome.

\section{METHODS}

\section{Ethical aspects}

The research started after the approval of the Research Ethics Committee of the Universidade Estadual Paulista "Júlio de Mesquita Filho," Botucatu Campus, São Paulo, Brazil, formalized under the opinion 563700. Participants who were aware and in favorable clinical conditions were invited to participate in the research. For unconscious patients, the invitation was made to the responsible family member. The formalization of participation occurred through the signing of the Free and Informed Consent Term, obeying the ethical precepts of Resolution 466/12, of the National Health Council.

\section{Study design and location}

A descriptive, cross-sectional study, with a quantitative design, guided by the STROBE tool, performed in an ICU for the treatment of burn patients belonging to a large, state, public hospital located in the interior of the state of São Paulo, Brazil.

The Unit consists of 4 beds for patients over the age of 18 , as those under age are treated at the institution's Pediatric ICU. The care is multidisciplinary. The nursing team consists of 1 nurse coordinator, four nurse assistants, and ten nursing technicians.

\section{Sample and inclusion criteria}

The sample consisted of 33 patients who were attended at the Unit between January and June 2017. The inclusion criterion consisted of the patient's length of stay in the ICU over 24 hours, following what the literature recommends, and similar studies show ${ }^{(3,11,13)}$. Another variable considered for establishing this inclusion criterion was the recommendation related to the application of the Severity Index "Simplified Acute Physiology Score - SAPS $3^{\prime \prime(14) .}$

\section{Study Protocol}

To assess the nursing workload, the NAS was used. This instrument consists of 7 categories and 23 items referring to therapeutic interventions and nursing care. The total NAS calculation, for each patient, represents the sum of the values assigned to each item, and its total score expresses, in percentage, the time spent by the nursing team during patient care in the 24 hours, with a maximum value of $176.8 \%$. Each NAS point corresponds to 0.24 hours $^{(11)}$.

The NAS was applied every 24 hours, retrospectively, by direct observation and also by consulting and collecting the records in the patient's electronic medical record aiming at standardization. We decided to apply the NAS daily at $7 \mathrm{pm}$. For patients who progressed to discharge or death, we considered the NAS score for the last 24 hours before the event. The study included admitted patients after the first 24 hours of hospitalization.

Data collection was carried out exclusively by three researchers. At first, in order to assess the agreement between them, we sought to conduct a pilot study with five patients, whom we did not include in the sample. The study pointed out divergences regarding the application of the NAS, a difficulty that literature describes ${ }^{(13)}$. Thus, 
we decided to make a tutorial about the application of NAS to unify understanding and increase agreement between the evaluators, in each item, the procedures to be scored were defined or explained. The construction of tutorials related to the NAS application has contributed to standardizing its application ${ }^{(15-16)}$, and its effectiveness in measuring the workload is evident ${ }^{(17)}$.

At the same time, the variables to categorize the participants were: intubation, use of vasoactive drugs, severity (SAPS 3), hospitalization outcome, length of stay, and body burned area (BBA). For this, an instrument made by the authors was used. Subsequently, the nursing workload required by the NAS was associated with each of these variables.

The nursing workload was considered as a dependent variable; and, as independent, the following variables: intubation, use of vasoactive drugs (dopamine, dobutamine or norepinephrine), BBA (minor, moderate and major burn) ${ }^{(18)}$, length of stay and hospitalization outcome (discharge or death) and severity (SAPS 3) ${ }^{(14)}$.

The calculation of the burn extent is classified according to age, differentiating between children and adults. One of the methods used to assess BBS is the "rule of nines." For body surfaces of short extension or that reaches only parts of the body segments, in adults, the size of the patient's palm is used to calculate the BBA, which is equivalent to $1 \%$ of the $\mathrm{BBA}^{(19)}$.

For the classification referring to $B B A$, the present study used the following definitions: minor burn - burns of second degree below $10 \%$ or third-degree below 5\%; moderate burn - second-degree burns from $10 \%$ to $25 \%$ or third-degree around $10 \%$; and major burn - second-degree burns above $25 \%$ or third-degree burns above $10 \%{ }^{(18)}$.

\section{Results analysis and statistics}

The data were analyzed using the Predictive Analytics Software - PASW ${ }^{\circledast}$ program. For qualitative variables, descriptive statistical analysis was used. In order to verify the association between the nursing workload (mean NAS) and the variables "intubation" and "use of vasoactive drugs," the Student's $t$-test was used; for the hospitalization outcome and the BBA, the Anova test. In order to assess the correlation between the nursing workload (mean NAS) and the variables "patient severity" and "length of stay," Spearman's Correlation was used. The level of significance was at $5 \%$ for all tests ( $p \leq 0.05)$. Still, the analysis of the forces of linear correlation was used, in which the value of 0.30 indicated weak correlation; $0.30-0.50$, moderate correlation; and above 0.50 , strong correlation ${ }^{(20)}$.

\section{RESULTS}

The sample consisted of 33 patients. Regarding gender, the male prevailed $(n=24)$. The age varied between 18 and 79 years old (mean of 47 years; $S D=14$ ). The length of hospital stay ranged from 2 to 36 days (mean of 15 days; SD $=5$ ). Concerning clinical variables, those who required intubation $(n=27)$ and those who used vasoactive drugs $(n=28)$ prevailed. Regarding BBA, there was a predominance of major burns $(n=28)$. Regarding the severity of the patients, the SAPS 3 average was 58 points (SD = 16.4). As for the hospitalization outcome, death prevailed $(n=29)$.

447 NAS assessments were generated. Regarding the nursing workload, the average value was $84 \%(S D=4.4)$, ranging from
75 to $91 \%$. Considering that each NAS point corresponds to 0.24 hours ${ }^{(11)}$, the nursing workload was 20.2 hours, referring to the work time required per patient in the 24 hours of assistance.

Regarding the frequency of NAS items, we observed that, in $100 \%$ of the evaluations, patients were scored on: monitoring and control; laboratory research; medication (except vasoactive drug); hygiene procedures; administrative and managerial tasks; mobilization and positioning; support and care for family members and patients; and quantitative measurement of urine output (Table 1).

Table 1 - Score of the Nursing Activities Score items in burn patients attended in the ICU, Bauru, São Paulo, Brazil, 2017

\begin{tabular}{lcc}
\hline \multicolumn{1}{c}{ NAS Items } & n & $\%$ \\
\hline 1. Monitoring and control & 447 & 100 \\
2. Laboratory investigations & 447 & 100 \\
3. Medication (except vasoactive drug) & 447 & 100 \\
4. Hygiene procedures & 447 & 100 \\
5. Drain care (except gastric tube) & 258 & 58 \\
6. Mobilization and positioning & 447 & 100 \\
7. Support and care for family members and patients & 447 & 100 \\
8. Administrative and managerial tasks & 447 & 100 \\
9. Ventilatory support & 211 & 47 \\
10. Care of artificial airways & 274 & 61 \\
11. Treatment for improving lung function & 366 & 82 \\
12. Vasoactive medication & 179 & 40 \\
13. Intravenous replacement of large fluid losses & 270 & 60 \\
16. Hemofiltration technique & 40 & 9 \\
17. Quantitative measurement of urine output & 447 & 100 \\
21. Enteral nutrition & 337 & 75 \\
22. Specific interventions in the ICU & 51 & 11 \\
23. Specific interventions outside the ICU & 83 & 18 \\
\hline Note: NAS= Nursing Activities Score. & &
\end{tabular}

When associating the nursing workload with the independent variables "need for intubation," "use of vasoactive drugs," "hospitalization outcome" and "BBA," we observed an association of nursing workload with the hospitalization outcome ( $p=0.020)$ and the BBA ( $p=0.010)$ (Table 2).

Table 2 - Association of the Nursing Activities Score mean with the independent variables "intubation," "use of vasoactive drugs," "hospitalization outcome" and " body burned area", Bauru, São Paulo, Brazil, 2017

\begin{tabular}{lccc}
\hline \multicolumn{1}{c}{ Variables } & $\begin{array}{c}\text { NAS mean } \\
(\%)\end{array}$ & $\begin{array}{c}\text { SD } \\
(\%)\end{array}$ & $\boldsymbol{p}$ value \\
\hline $\begin{array}{l}\text { Intubation } \\
\quad \text { No }\end{array}$ & 81 & 3,4 & $0,310 \Omega$ \\
$\quad$ Yes & 84 & 4,1 & \\
Use of vasoactive drugs & & & \\
$\quad$ No & 81 & 3,4 & $0,240 \Omega$ \\
$\quad$ Yes & 85 & 4,3 & \\
Hospitalization outcome & & & \\
$\quad$ Discharge & 81 & 3,1 & $0,020 * \beta$ \\
$\quad$ Death & 86 & 5,0 & \\
Body burned area & & & \\
$\quad$ Major burn & 85 & 4,3 & $0,010 * \beta$ \\
$\quad$ Moderate burn & 81 & 4,3 & \\
$\quad$ Minor burn & 80 & 1,5 & \\
\end{tabular}

Note: $\Omega$ : Student's t test; $\beta$ : ANOVA test * statistical significance ( $p \leq 0.05) ;$ NAS: Nursing Activities Score; SD: Standard deviation. 
Table 3 - Correlation between nursing workload (mean Nursing Activities Score) and the variables "patient's severity" and "length of stay", Bauru, São Paulo, Brazil, 2017

\begin{tabular}{lcc}
\hline \multicolumn{1}{c}{ Variables } & R & $\boldsymbol{p}$ value \\
\hline NAS $\times$ Severity - SAPS 3 & 0,47 & $<0,001^{*}$ \\
NAS $\times$ Length of stay & $-0,10$ & 0,550 \\
\hline Note: ${ }^{*}$ Spearman's correlation, statistical significance of $p \leq 0.05 ;$ NAS $=$ Nursing & Activities Score.
\end{tabular}

When relating the nursing workload to the patient's severity (SAPS 3) and length of stay, we observed a moderate correlation between the nursing workload and the patient's severity ( $p$ $<0.001$ ) (Table 3).

\section{DISCUSSION}

This study identified that burn victim patients had a NAS mean of $84 \%$; that is, they demanded a nursing workload of 20.2 hours, referring to the work time required per patient in the 24 hours of assistance. A similar investigation showed that the nursing workload was $70 \%$ (16.9 hours) $)^{(3)}$, therefore, lower than that observed in this study.

We highlight that the nursing workload shown in the present study was higher than that established by the Resolution of the Federal Council of Nursing, as a minimum standard of time for intensive care of 18 hours $^{(21)}$. In this sense, a study carried out in an ICU destined exclusively to the care of adult patients, of different medical specialties, pointed out a 19.03 hour NAS nursing workload $^{(22)}$. In another investigation with intensive care patients in the immediate postoperative period of cardiac surgery, the value was 19.77 hours $^{(23)}$. In conclusion, these findings reinforce the hypothesis that the nursing workload may have a longer care time, depending on the work process in its clinical and managerial specificities.

It is known that the qualitative and qualitative adequacy of professionals directly influences the quality of care and, in turn, patient safety. Among its benefits, the lowest incidence of iatrogenesis and adverse events, infections related to healthcare, readmissions, and mortality stand out ${ }^{(24-28)}$.

These findings reinforce the need to measure the nursing workload in different work processes, mainly because several variables influence it, including the degree of patient dependence, the complexity of pathologies, work processes, institutional philosophy, professionals' profile, inadequate physical space, shortage of material resources, among others ${ }^{(29-32)}$.

Even in similar care profiles, there are significant differences regarding the nursing workload ${ }^{(23,33)}$. In addition to providing subsidies for calculating hospital staffing, the assessment of nursing workload contributes both to the division of labor according to professional categories and to the measurement of the care required by a given group of patients ${ }^{(34-36)}$.

When assessing the frequency of NAS items, predominated monitoring and control; laboratory research; medication (except vasoactive drug); hygiene procedures; administrative and managerial tasks; mobilization and positioning; support and care for family members and patients; and quantitative measurement of urine output - all pointing to the complexity of patients affected by burns. Another investigation evidenced a similar result ${ }^{(3)}$.

In the present study, concerning BBA, major burns prevailed, corroborating the literature ${ }^{(29)}$. Burns that reach extensive body lengths denote greater severity, longer hospital stay, and, consequently, contribute to complications and deaths. These factors increase the nursing workload ${ }^{(3,29)}$.

We also observed that the nursing workload is associated with the patient's severity, that is, the higher the severity, the greater the nursing workload, in accordance with the literature ${ }^{(30,35,37)}$. However, other publications pointed out that the patients' severity is not necessarily linked to the high nursing workload and related this finding to the early evolution of patients to death and the sophisticated technological support linked to nursing care $\mathrm{c}^{(23,38)}$.

It was also evident that the nursing workload was associated with the hospitalization outcome, that is, patients whose nursing workload was higher evolved to death, corroborating the literature ${ }^{(23,36,39)}$. In contrast, an investigation that included 324 patients found that the nursing workload was not considered a predictor of ICU mortality. However, this study considered only the first 24 hours of hospitalization ${ }^{(22)}$.

Studies have shown the percentage of deaths in burn ICU to be high nationally and internationally ${ }^{(3,40)}$. Among the etiological factors related to patients' severity, there is the health professionals' lack of preparation for the management of burn victims, particularly in the first hours after the event. Often, there are situations experienced in which patients arrive late for specialized treatment and, in unfavorable conditions, demonstrating that optimizing the initial care of these patients poses a significant challenge to the health system.

The delay in transferring patients to specialized units and the delay in starting treatment, with an emphasis on volume replacement, are identified as contributing to the poor prognosis ${ }^{(40-41)}$.

\section{Study Limitations}

The monocentric characteristic of the study does not allow generalization of the results. Still, the scarcity of similar studies limited the comparisons. In this context, we encourage further research, aiming to consolidate the knowledge established here.

\section{Contributions to the nursing field}

The definition of the nursing workload is essential for adequate staffing. Thus, the results found here may support nurses and managers in decision making in response to the work demands of nursing professionals working in this unit and, in turn, contribute to improvements in the quality of care, patient safety, and higher professional satisfaction in the workplace.

\section{CONCLUSION}

Burn victims, assisted in the ICU, demanded a high nursing workload, which was influenced by clinical aspects and the hospitalization outcome. These findings point to the need to reconsider the nurse staffing related to this care profile. 


\section{REFERENCES}

1. Kirby E, Hurst K. Using a complex audit tool to measure workload, staffing and quality in district nursing. Br J Community Nurs. 2014;19(5):219-23. doi: 10.12968/bjen.2014.19.5.219

2. Magalhães AMM, Costa DG, Riboldi CO, Mergen T, Barbosa AS, Moura GMSS. Association between workload of the nursing staff and patient safety outcomes. Rev Esc Enferm USP [Internet]. 2017 [cited 2019 May 15];51:e03255. Available from: http://www.scielo.br/pdf/reeusp/ v51/1980-220X-reeusp-51-e03255.pdf

3. Camuci MB, Martins JT, Cardeli AAM, Robazzi MLCC. Nursing Activities Score: nursing work load in a burn Intensive Care Unit. Rev LatinoAm Enfermagem [Internet]. 2014 [cited 2019 May 15];22(2):325-31. Available from: http://www.scielo.br/pdf/rlae/v22n2/0104-1169rlae-22-02-00325.pdf

4. Echevarría-Guanilo ME, Gonçalves N, Farina JA, Rossi LA. Assessment of health-related quality of life in the first year after burn. Esc Anna Nery [Internet]. 2016 [cited 2019 May 15];20(1):155-166. Available from: http://www.scielo.br/pdf/ean/v20n1/en_1414-8145-ean-20-01-0155.pdf

5. Martins JT, Bobroff MCC, Ribeiro RP, Soares MH, Robazzi MLCC, Marziale MHP. Feelings experienced by the nursing team at a burns treatment center. Esc Anna Nery [Internet]. 2014 [cited 2019 May 15];18(3):522-526. Available from: http://www.scielo.br/pdf/ean/v18n3/ en_1414-8145-ean-18-03-0522.pdf

6. Padillha KG, Barbosa RL, Andolhe R, Oliveira EM, Ducci AJ, Bregalda RS, et al. Nursing workload, stress/burnout, satisfaction and incidents in a trauma intensive care units. Texto Contexto Enferm [Internet]. 2017 [cited 2019 May 15];26(3):e1720016. Available from: http://www.scielo. br/pdf/tce/v26n3/en_0104-0707-tce-26-03-e1720016.pdf

7. Salehi A, Javanbakht M, Ezzatababdi MR. Stress and its determinants in a sample of Iranian nurses. Holist Nurs Pract. 2014;28(5):323-8. doi: 10.1097/HNP.0000000000000043.

8. Oliveira BLCA, Lima AMSSF. Carga semanal de trabalho para enfermeiros no Brasil: desafios ao exercício da profissão. Trab Educ Saúde[Internet]. 2018 [cited 2019 May. 15];16(3):1221-36. Available from: http://www.scielo.br/pdf/tes/v16n3/1678-1007-tes-1981-7746-sol00159.pdf

9. Carvalho DP, Rocha LP, Tomaschewski-Barlem JG, Barlem ELD, Cecagno D, Dalmolin GL. Productivity versus workloads in the nursing working environment. Rev Esc Enferm USP [Internet]. 2017 [cited 2019 May 15];51:e03301. Available from: http://www.scielo.br/pdf/reeusp/ v51/1980-220X-reeusp-S1980-220X2017028903301.pdf

10. Trettene AS, Fontes CMB, Razera APR, Prado PC, Bom GC, Kostrisch LMV. Sizing of personnel to promote self-care in a Pediatric Semi-Intensive Unit. Rev Bras Ter Intensiva [Internet]. 2017 [cited 2019 May 15];29(2):171-9. Available from: http://www.scielo.br/pdf/rbti/v29n2/en_0103507X-rbti-29-02-0171.pdf

11. Miranda DR, Nap R, Rijk A, Schaufeli W, Lapichino G. TISS Working Group. Therapeutic Intervention Scoring System. Nursing Activities Score. Crit Care Med [Internet]. 2003 [cited 2019 May 15];31(2):374-82. Available from: https://insights.ovid.com/pubmed?pmid=12576939

12. Queijo AF, Padilha KG. Nursing Activities Score (NAS): Cross-cultural adaptation and validation to Portuguese language. Rev Esc Enferm USP [Internet]. 2009 [cited 2019 May 15];43(n.spe):1018-25. Available from: http://www.scielo.br/pdf/reeusp/v43nspe/en_a04v43ns.pdf

13. Padilha KG, Stafseth S, Solms D, Hoogendoom M, Monge FJC, Gomaa OH, et al. Nursing Activities Score: an updated guideline for its application in the Intensive Care Unit. Rev Esc Enferm USP [Internet]. 2015 [cited 2019 May 15];49(n.spe):131-7. Available from: http://www. scielo.br/pdf/reeusp/v49nspe/1980-220X-reeusp-49-spe-0131.pdf

14. Moreno RP, Metnitz PG, Almeida E, Jordan B, Bauer P, Campos RA, et al. SAPS 3 - From evaluation of the patient to evaluation of the intensive care unit. Part 2: Development of a prognostic model for hospital mortality at ICU admission. Intensive Care Med [Internet]. 2005 [cited 2019 May 15];31:1345-55. Available from: https://www.ncbi.nlm.nih.gov/pmc/articles/PMC1315315/pdf/134_2005_Article_2763.pdf

15. Trettene AS, Fontes CMB, Razera APR, Gomide MR. Application of Nursing Activities Score in specialized semi-intensive unit: construction and validation of a tutorial. J Nurs UFPE[Internet]. 2016 [cited 2019 May 15];10(12):680-5. Available from: https://periodicos.ufpe.br/revistas/ revistaenfermagem/article/view/11508/13385

16. Silva TCMS, Castro MCN, Popim RC. Adaptation of the Nursing Activities Score for oncologic care. Rev Bras Enferm [Internet]. 2018 [cited 2019 May 15];71(5):2383-91. Available from: http://www.scielo.br/pdf/reben/v71n5/0034-7167-reben-71-05-2383.pdf

17. Ferreira PC, Machado RC, Martins QCS, Sampaio SF. Classification of patients and nursing workload in intensive care: comparison between instruments. Rev Gaúcha Enferm [Internet]. 2017 [cited 2019 May 15];38(2):e62782. Available from: http://www.scielo.br/pdf/rgenf/v38n2/ en_0102-6933-rgenf-1983-144720170262782.pdf

18. Fundação Hospitalar do Estado de Minas Gerais. Diretrizes Clínicas - Protocolos Clínicos. Atendimento ao queimado. Minas Gerais; 2013. 296p.

19. Marko P, Layon AJ, Caruso L, Mozingo DW, Gabrielli A. Burn injuries. Curr Opin Anaesthesiol [Internet]. 2003 [cited 2019 May 15];16:183-91. Available from: https://www.ncbi.nlm.nih.gov/pubmed/17021458

20. Mukaka MM. Statistics Corner: A guide to appropriate use of correlation coefficient in medical research. Malawi Med J [Internet]. 2012 [cited 2019 Dec 03];24(3):69-71. Available from: https://www.ncbi.nlm.nih.gov/pmc/articles/PMC3576830/pdf/MMJ2403-0069.pdf

21. Conselho Federal de Enfermagem. Resolução n. 527, de 03 de novembro de 2016. Atualiza e estabelece parâmetros para o Dimensionamento do Quadro de Profissionais de Enfermagem nos serviços/locais em que são realizadas atividades de enfermagem [Internet]. Brasília; 2016 [citado 2019 mai. 15]. Disponível em: http://novo.portalcofen.gov.br/resoluo-cofen-2932004_4329.html 
22. Nassif A, Araújo TR, Meneguetti MG, Bellissimo-Rodrigues F, Basile-Filho A, Laus AM. Nursing workload and the patient mortality at an Intensive Care Unit. Texto Contexto Enferm [Internet]. 2018 [cited 2019 May 15];27(4):e0390017. Available from: http://www.scielo.br/pdf/ tce/v27n4/en_0104-0707-tce-27-04-e0390017.pdf

23. Oliveira LB, Rodrigues ARB, Püschel VAA, Silva FA, Conceição SL, Béda LB, et al. Assessment of workload in the postoperative period of cardiac surgery according to the Nursing Activities Score. Rev Esc Enferm USP [Internet]. 2015 [cited 2019 May 15];49(n.spe):79-85. Available from: http://www.scielo.br/pdf/reeusp/v49nspe/en_1980-220X-reeusp-49-spe-0080.pdf

24. Valentin A, Schiffinger M, Steyrer J, Huber C, Strunk G. Safety climate reduces medication and dislodgement errors in routine intensive care practice. Intensive Care Med. 2013;39(3):391-8. doi: 10.1007 / s00134-012-2764-0.

25. Liu JT, Song HJ, Wang Y, Kang Y, Jiang L, Lin SH, et al. Factors associated with low adherence to head-of-bed elevation during mechanical ventilation in Chinese intensive care units. Chin Med J[Internet]. 2013 [cited 2019 May 15];126(5):834-8. Available from: https://insights.ovid. com/pubmed?pmid=23489786

26. Cremasco MF, Wenzel F, Zanei SS, Whitaker IY. Pressure ulcers in the intensive care unit: the relationship between nursing workload, illness severity and pressure ulcer risk. J Clin Nurs [Internet]. 2013 [cited 2019 May 15];22(15-16):2183-91. Available from: https://onlinelibrary. wiley.com/doi/pdf/10.1111/j.1365-2702.2012.04216.x

27. Novaretti MCZ, Santos EV, Quitério LM, Daud-Gallotti RM. Nursing workload and occurrence of incidents and adverse events in ICU patients. Rev Bras Enferm [Internet]. 2014 [cited 2019 May 15];67(5):692-9. Available from: http://www.scielo.br/pdf/reben/v67n5/0034-7167reben-67-05-0692.pdf

28. Toffoletto MC, Oliveira EM, Andolhe R, Barbosa RL, Padilha KG. Comparison between patient severity and nursing workload before and after the occurrence of adverse events in elderly in critical care. Texto Contexto Enferm [Internet]. 2018 [cited 2019 May 15]; 27 (1):e3780016. Available from: http://www.scielo.br/pdf/tce/v27n1/en_0104-0707-tce-27-01-e3780016.pdf

29. Park JO, Shin SD, Kim J, Song KJ, Peck MD. Association between socioeconomic status and burn injury severity. Burns. 2009;35(4):482-90. doi: 10.1016 / j.burns.2008.10.007

30. Peng L, Mayner L, Wang H. Association between trauma patients' severity and critical care nursing workload in China. Nurs Health Sci. 2014;16(4):528-33. doi: 10.1111 / nhs.12141

31. Altafin JAM, Grion CMC, Tanita MT, Festti J, Cardoso LTQ, Veiga CF, et al. Nursing Activities Score e carga de trabalho em unidade de terapia intensiva de hospital universitário. Rev Bras Ter Intensiva [Internet]. 2014 [citado 2019 mai. 15];26(3):292-8. Available from: http://www. scielo.br/pdf/rbti/v26n3/0103-507X-rbti-26-03-0292.pdf

32. Oliveira AC, Garcia PC, Nogueira LS. Nursing workload and occurrence of adverse events in intensive care: a systematic review. Rev Esc Enferm USP [Internet]. 2016 [cited 2019 May 15];50(4):679-89. Available from: http://www.scielo.br/pdf/reeusp/v50n4/0080-6234-reeusp-50-04-0683.pdf

33. Trettene AS, Luiz AG, Razera APR, Maximiano TO, Cintra FMRN, Monteiro LM. Nursing workload in specialized Semi-intensive Therapy Unit: workforce size criteria. Rev Esc Enferm USP [Internet]. 2015 [cited 2019 May 15];49(6):960-6. Available from: http://www.scielo.br/pdf/ reeusp/v49n6/0080-6234-reeusp-49-06-0960.pdf

34. Nogueira LS, Koike KM, Sardinha DS, Padilha KG, Sousa RM. Nursing workload in public and private intensive care units. Rev Bras Ter Intensiva [Internet]. 2013 [cited 2019 May 15];25(3):225-32. Available from: http://www.scielo.br/pdf/rbti/v25n3/en_0103-507x-rbti-25-03-0225.pdf

35. Sousa VMD, Santos TDS, Reis RBDAC, Caldas TDM, Gomes ET, Cavalcanti ATDA. Nursing workload and intervention in a therapeutic intensive care unit. J Nurs UFPE on line [Internet]. 2015 [cited 2019 May 15];9(6):8172-8. Available from: https://periodicos.ufpe.br/revistas/ revistaenfermagem/article/view/10575/11518

36. Cyrino CMS, Dell'Acqua MCQ, Castro MCN, Oliveira EM, Deodato S, Almeida PMV. Nursing Activities Score by assistance sites in Intensive Care Units. Esc Anna Nery [Internet]. 2018 [cited 2019 May 15];22(1):e20170145. Available from: http://www.scielo.br/pdf/ean/v22n1/14148145-ean-2177-9465-EAN-2017-0145.pdf

37. Lachance J, Douville F, Dallaire C, Padilha KG, Gallani MC. The use of the Nursing Activities Score in clinical settings: an integrative review. Rev Esc Enferm USP [Internet]. 2015 [cited 2019 May 15];49(n.spe):147-56. Available from: http://www.scielo.br/pdf/reeusp/v49nspe/1980220X-reeusp-49-spe-0147.pdf

38. Goulart LL, Aoki RL, Vegian CFL, Guirardello EB. Carga de trabalho de enfermagem em uma unidade de terapia intensiva de trauma. Rev Eletr Enferm [Internet]. 2014 [cited 2019 May 15];16(2):346-51. Available from: https://www.fen.ufg.br/fen_revista/v16/n2/pdf/v16n2a10.pdf

39. Beccaria LM, Contrin LM, Cesarino CB, Silva DC, Silva APA, Werneck AL. Association between nursing workload and the patient prognosis in Intense Care Unit. Business Management Review. 2015;4(5):731-8. doi: 10.1111 / j.1547-5069.2008.00254.x

40. Theodorou P, Xu W, Weinand C, Perbix W, Maegele M, Lefering R, et al. Incidence and treatment of burns: a twenty-year experience from a single center in Germany. Burns. 2013;39:49-54. doi: 10.1016 / j.burns.2012.05.003.

41. Serra MCVF, Saki AL, Cruz PFS, Santos MFP, MacieL L. Perfil epidemiológico dos idosos de queimaduras do centro de tratamento de queimados Doutor Plassant do Hospital Federal de Andaraí - Rio de Janeiro - RJ. Rev Bras Queimadura [Internet]. 2014 [cited 2019 mai. 15];13(2):90-4. Available from: http://www.rbqueimaduras.com.br/how-to-cite/205/pt-BR 